\title{
Additions to the Vascular Flora of Ontario, Canada, from the Sutton Ridges, Hudson Bay Lowland Ecoregion
}

\author{
Michael J. Oldham ${ }^{1}$ and SAmuel R. BRinKeR ${ }^{2}$
}

${ }^{1}$ Ontario Natural Heritage Information Centre (NHIC), Ontario Ministry of Natural Resources, 300 Water Street, 2nd Floor, North Tower, P.O. Box 7000 Peterborough, Ontario K9J 8M5 Canada; email: michael.oldham@ontario.ca

${ }^{2}$ Ontario Natural Heritage Information Centre (NHIC), Ontario Ministry of Natural Resources, 300 Water Street, 2nd Floor, North Tower, P.O. Box 7000 Peterborough, Ontario K9J 8M5 Canada; email: sam.brinker@ontario.ca

Oldham, Michael J., and Samuel R. Brinker. 2011. Additions to the vascular flora of Ontario, Canada, from the Sutton Ridges, Hudson Bay Lowland ecoregion. Canadian Field-Naturalist 125(3): 241-247.

Field studies in the Hudson Bay Lowland ecoregion of northern Ontario during 2010 resulted in the discovery of four native vascular plant species not previously confirmed from the province: Arctic Bellflower (Campanula uniflora; Campanulaceae), Lapland Diapensia (Diapensia lapponica; Diapensiaceae), Alpine Azalea (Kalmia procumbens; Ericaceae), and Alpine Brook Saxifrage (Saxifraga rivularis; Saxifragaceae). These four species are widespread arctic plants occurring in both North America and Eurasia and were found on the Sutton Ridges, a Precambrian bedrock inlier surrounded by the extensive wetlands of the Hudson Bay Lowland.

Key Words: Arctic Bellflower, Campanula uniflora, Campanulaceae, Lapland Diapensia, Diapensia lapponica, Diapensiaceae, Alpine Azalea, Kalmia procumbens, Ericaceae, Alpine Brook Saxifrage, Saxifraga rivularis, Saxifragaceae, Hudson Bay Lowland ecoregion, Sutton Ridges, range extensions, new records, arctic-alpine, Ontario, Canada.

Fieldwork in northern Ontario was conducted by Ontario Ministry of Natural Resources staff as part of the provincial Far North community-based land use planning initiative. This fieldwork is aimed primarily at improving our knowledge of the natural features and biodiversity values of potential protected areas and is being conducted in collaboration with local First Nations communities. Some of the work in 2010 took place in the Sutton Ridges, a series of Precambrian granitic outcrops in the Hudson Bay Lowland. The Sutton Ridges are an unusual geological feature in the otherwise largely flat and wet Phanerozoic Hudson Bay Lowland (Riley 2011). Several other vascular plant species are known largely or exclusively from these acidic bedrock outcrops in Ontario, e.g., Northern Bentgrass (Agrostis mertensii), Alpine Sweetgrass (Anthoxanthum monticola), Northern Woodrush (Luzula confusa), and Greenland Stitchwort (Minuartia groenlandica) (Riley and Walshe 1985; Riley 2003). Continentally, these acidic granite upland habitats are isolated from equivalent Precambrian subarctic habitats at least $400 \mathrm{~km}$ to the west and east by Paleozoic lowlands, marine clay flats, peatlands, and ocean, and from boreal habitats $200 \mathrm{~km}$ to the southwest by Paleozoic lowlands, marine clay flats, and peatlands. These disjunct habitats were also among the earliest upland islands to emerge above the postglacial Tyrrell Sea 8500 YBP (McAndrews et al. 1982).

During the 2010 field studies, four vascular plant species not previously documented from Ontario (Scoggan 1978, 1979; Morton and Venn 1990; Newmaster et al. 1998; Kartesz 1999; Riley 2003; Brouillet et al. $2011^{*}$ ) were encountered in the Sutton Ridges area (Figure 1). All four species have been added to the list of provincially significant species tracked by the Ontario Natural Heritage Information Centre (NHIC). They are ranked S1 (critically imperilled) in the province (Ontario Ministry of Natural Resources 2012*).

Details on the additions are presented below. Herbarium acronyms follow Thiers (2011*).

\section{Campanulaceae}

Campanula uniflora L. (Arctic Bellflower)KENORA DISTRICT: Precambrian bedrock outcrop, ca. $65 \mathrm{~km} \mathrm{~S}$ of Hudson Bay coast, ca. $83 \mathrm{~km}$ ESE of Peawanuck, shaded, moist north-facing cliff base, flowering (but mostly in bud) patch of ca. 100 plants, with Fragile Fern (Cystopteris fragilis), Black Crowberry (Empetrum nigrum), Bog Labrador Tea (Rhododendron groenlandicum), and Rusty Woodsia (Woodsia ilvensis), 54.689, -84.262, 6 July 2010, M. J. Oldham \& C. Latremouille 37798 (TRT); Precambrian bedrock outcrop, $98 \mathrm{~km}$ SE of Peawanuck Airport, $5 \mathrm{~km}$ E of Aquatuk Lake, Sutton Ridges, 12 flowering clumps on cool, dry, shaded shale and sandstone cliff base overlain by diabase with Bog Birch (Betula pumila), Northern Sedge (Carex deflexa), Northern Single-spike Sedge (C. scirpoidea), Cystopteris fragilis, Rhododendron groenlandicum, Lapland Rosebay (R. lapponicum), Hairy Willow (Salix vestita), Bog Blueberry (Vaccinium uliginosum), and Lingonberry (V. vitis-idaea), 54.304, -84.488, 7 July 2010, S. R. Brinker 1640 (CAN, MICH).

In 2010, Arctic Bellflower (Figure 2) was located at two sites on the Sutton Ridges. Arctic Bellflower is a showy perennial wildflower that is a widespread species in the High Arctic. It is rare in large parts of its range (Ægisdóttir and Thórhallsdóttir 2006). It occurs 


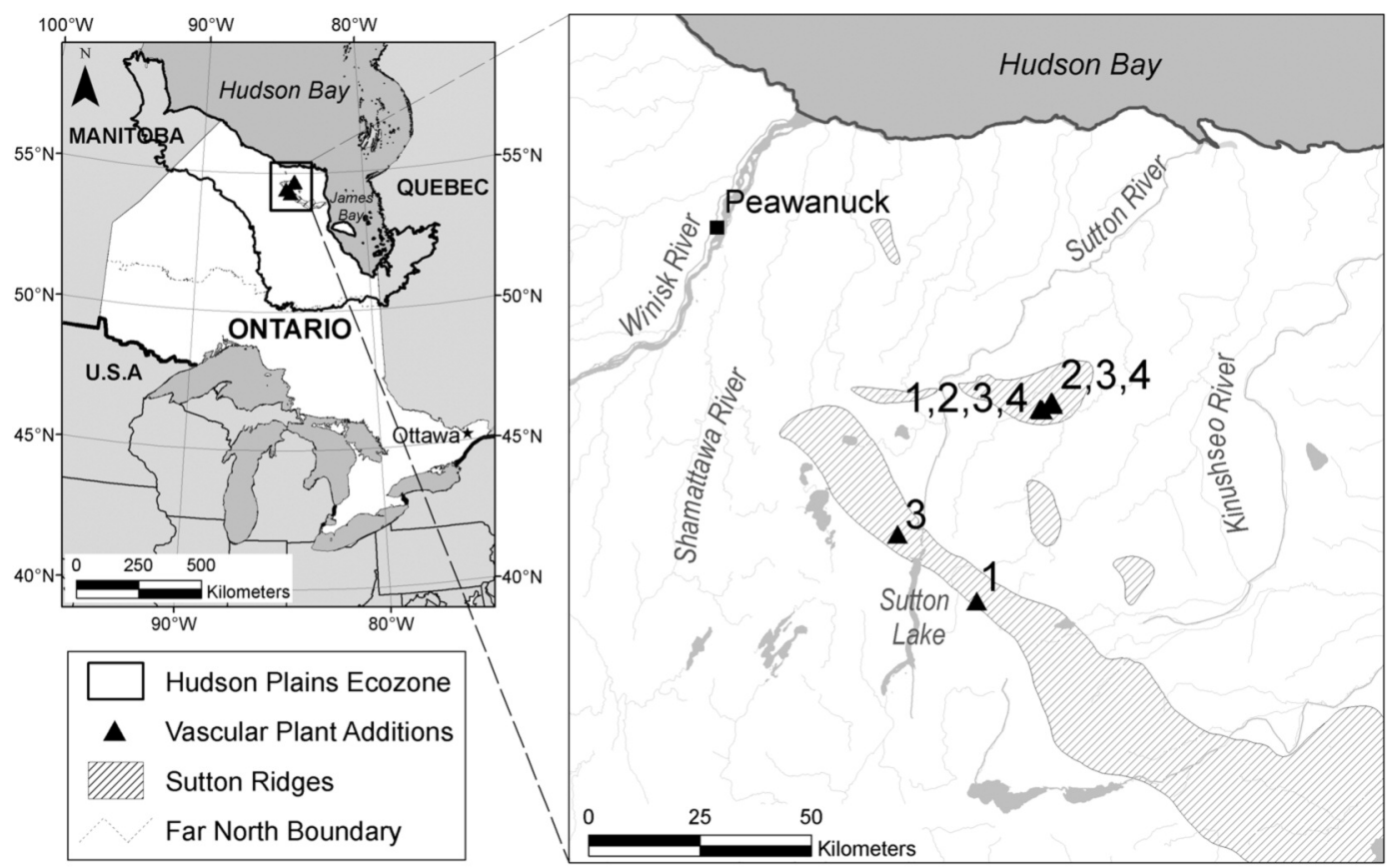

FIGURE 1. Map showing general location of study area within the Hudson Bay Lowland ecoregion, northern Ontario. Numbered triangles represent locations of vascular plant additions: (1) Arctic Bellflower (Campanula uniflora), (2) Lapland Diapensia (Diapensia lapponica), (3) Alpine Azalea (Kalmia procumbens), and (4) Alpine Brook Saxifrage (Saxifraga rivularis).

in arctic North America as well as western Europe and eastern Asia (Hultén 1968). In the southern Hudson Bay region, it is also known from Churchill, Manitoba, the coast of Hudson Strait, and the eastern Hudson Bay coast, south to Pointe Louis-XIV (Cape Jones), 54 ${ }^{\circ} 37^{\prime} \mathrm{N}$ (Scoggan 1979; Blondeau and Cayouette 2002). Campanula uniflora is uncommon to rare in the Churchill area (Johnson 1987).

With its single, nodding, pale blue flowers, Campanula uniflora is unlikely to be confused with other species in the flora of the Hudson Bay Lowland, except for Bluebell (C. rotundifolia), which has a glabrous calyx (pubescent in $C$. uniflora) and often multiple flowers per stem.

\section{Diapensiaceae}

Diapensia lapponica L. (Lapland Diapensia)— KENORA DISTRICT: Precambrian bedrock outcrop, ca. $65 \mathrm{~km} \mathrm{~S}$ of Hudson Bay coast, ca. $83 \mathrm{~km}$ ESE of Peawanuck, mossy, exposed ledge, north-facing, rare and local, with Empetrum nigrum and Vaccinium uliginosum, $54.689,-84.258,6$ July 2010, M. J. Oldham \& C. Latremouille 37780 (CAN, MICH, NHIC, TRT); Precambrian bedrock outcrop, $84 \mathrm{~km}$ ESE of Peawanuck Airport, $27 \mathrm{~km}$ ENE of Hawley Lake, exposed rocky outcrop with Bigelow's Sedge (Carex bigelowii), Tufted Bulrush (Trichophorum cespitosum), Vaccinium uliginosum, and $V$. vitis-idaea, 54.703, $-84.222,11$ July 2010, S. R. Brinker 1723 (DAO, TRT).

In 2010, Diapensia lapponica (Figure 3) was collected at two sites on the Sutton Ridges. It was also noted at a third site growing on a low north-facing cliff above wetland, with Capitate Sedge (Carex capitata), Rhododendron groenlandicum, Marsh Labrador Tea (R. tomentosum), and Vaccinium uliginosum (M. J. Oldham, sight record). Diapensia lapponica is an arctic and subarctic low shrub restricted to high-latitude areas of the Northern Hemisphere (Nesom 2009). Day and Scott $(1981,1984)$ studied the autecology and biology of Diapensia lapponica in Newfoundland and provided a map of its North American distribution (Day and Scott 1984). Although Diapensia lapponica is known from northern Manitoba (Baralzon Lake, $\left.60^{\circ} \mathrm{N}\right)$ and the eastern James Bay coast in Quebec (Scoggan 1979), it has not been previously reported from Ontario or from the Hudson Bay Lowland. In 2010, populations of Diapensia lapponica were located on two Precambrian Shield granitic rock outcrops close to each other in the Sutton Ridges area, adding a new species and a new family to the Ontario flora.

\section{Ericaceae}

Kalmia procumbens (L.) Gift \& Kron (Alpine Azalea)-KENORA DISTRICT: Precambrian bedrock out- 


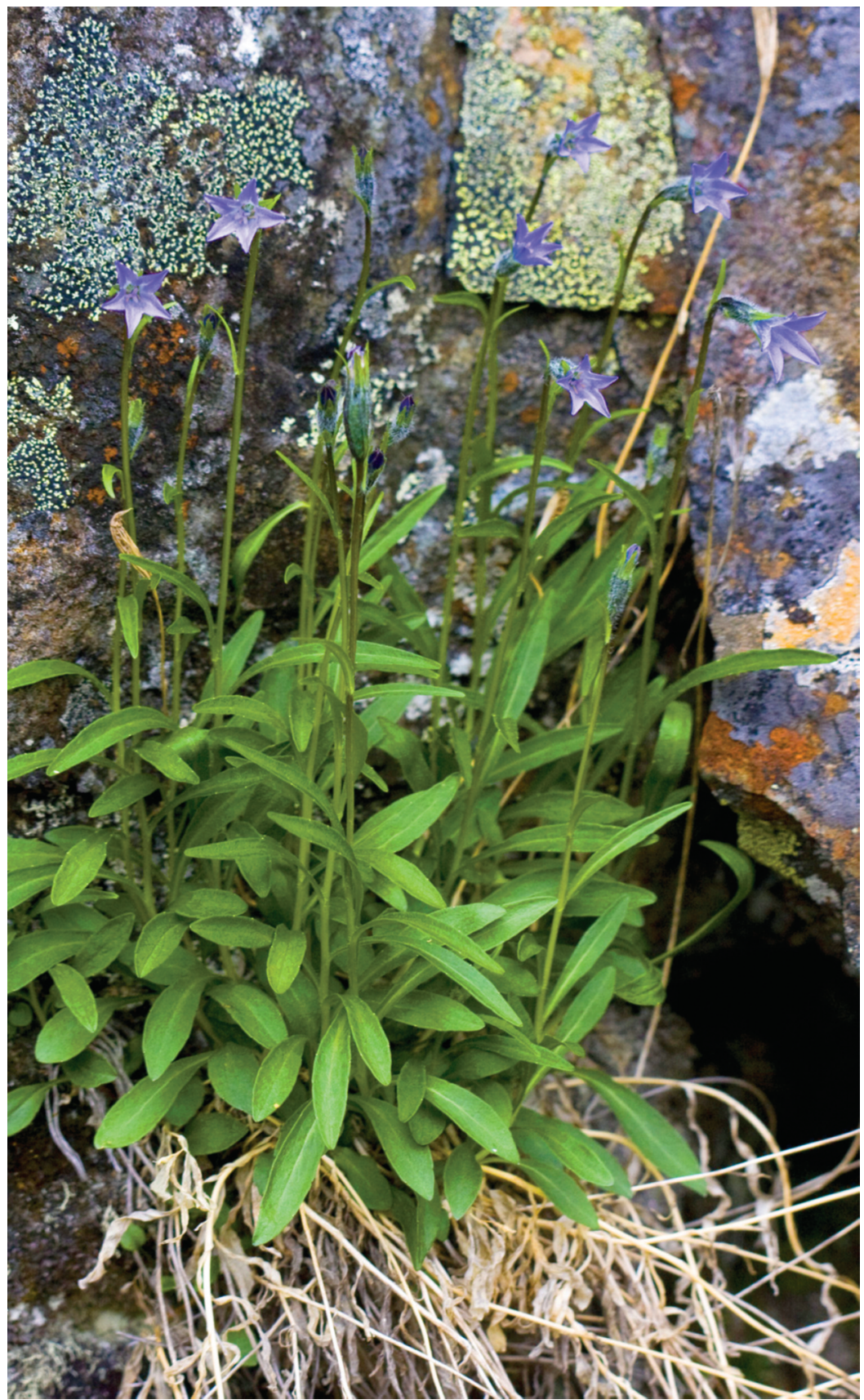

FiguRE 2. Arctic Bellflower (Campanula uniflora) on the Sutton Ridges, Ontario, 7 July 2010. Photo: S. R. Brinker.

crop, $75 \mathrm{~km}$ SE of Peawanuck Airport, $1.6 \mathrm{~km} \mathrm{SE} \mathrm{of}$ Raft Lake, Sutton Ridges area of interest, over shallow mossy bedrock in perched fen with Northern Bog Sedge (Carex gynocrates), Tussock Cottongrass (Eriophorum vaginatum), and Alpine Bulrush (Trichophorum alpi- num), 54.439, $-84.761,3$ July 2010, S. R. Brinker 1540 (CAN, TRT); Precambrian bedrock outcrop, ca. $65 \mathrm{~km}$ S of Hudson Bay coast, ca. $83 \mathrm{~km}$ ESE of Peawanuck, moss-covered edges of exposed bedrock, with Bog Rosemary (Andromeda polifolia), Empetrum nigrum, 


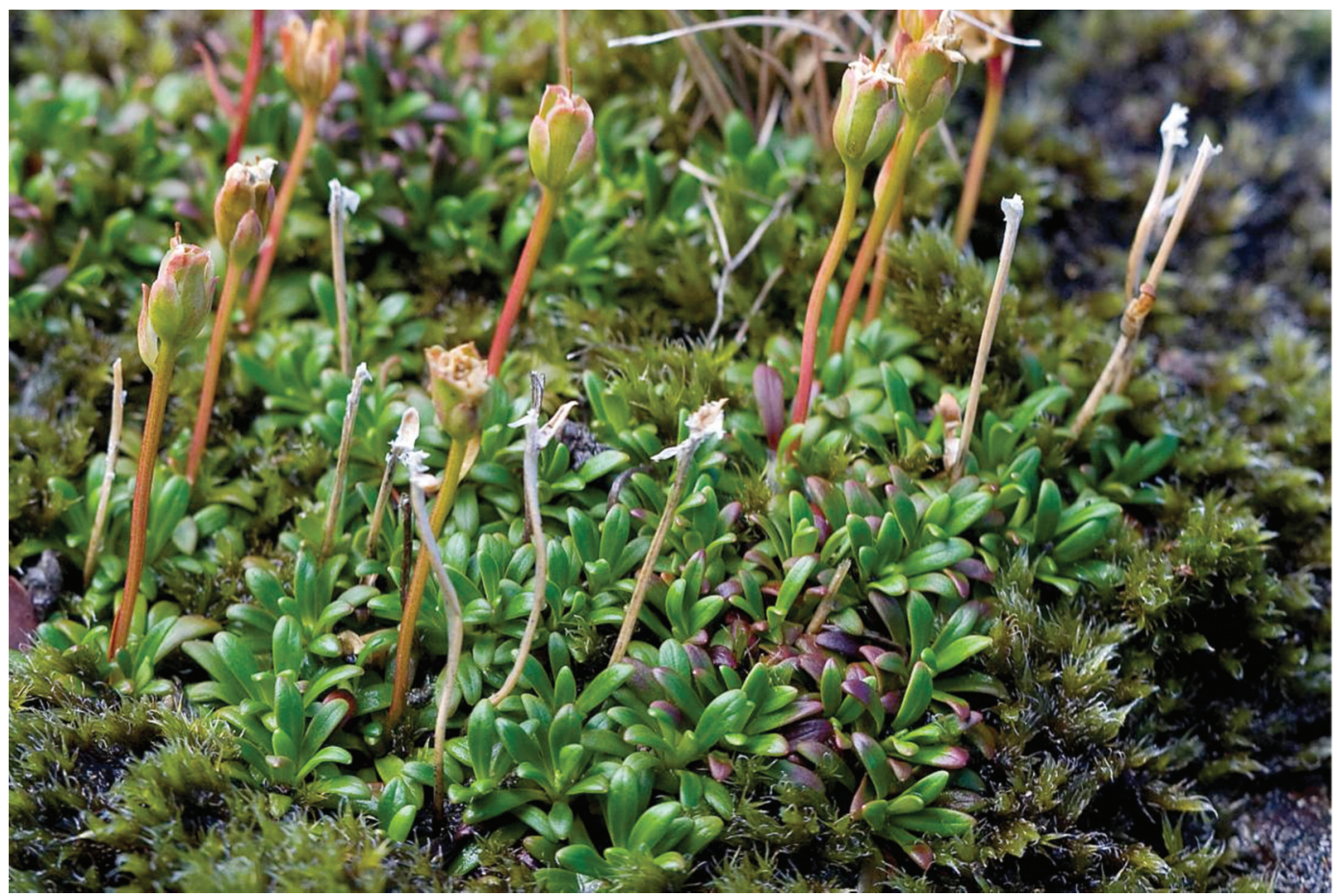

Figure 3. Lapland Diapensia (Diapensia lapponica) on the Sutton Ridges, Ontario, 11 July 2010. Photo: S. R. Brinker.

Black Spruce (Picea mariana), Rhododendron tomentosum, Cloudberry (Rubus chamaemorus), and Vaccinium vitis-idaea, $54.688^{\circ},-84.257^{\circ}, 6$ July 2010, M. J. Oldham \& C. Latremouille 36682 (NHIC, TRT); Precambrian bedrock outcrop, $84 \mathrm{~km}$ ESE of Peawanuck Airport, $27 \mathrm{~km}$ ENE of Hawley Lake, exposed rocky outcrop with Agrostis mertensii, Carex capitata, C. deflexa, and Vaccinium vitis-idaea, 54.704, -84.222, 11 July 2010, S. R. Brinker 1717 (MICH).

In 2010, Kalmia procumbens (Figure 4) was collected at three sites close to each other on the Sutton Ridges (Figure 5). Kalmia procumbens was also noted at two other sites growing on the edges of rock outcrops with reindeer lichen (Cladina sp.), Empetrum nigrum, Kalmia polifolia, Stiff Clubmoss (Lycopodium annotinum), Rhododendron tomentosum, and Vaccinium uliginosum (M. J. Oldham, sight record); and several small patches were observed on shallow, moist mossy bedrock with Loose-flowered Alpine Sedge (Carex rariflora), Empetrum nigrum, and Kalmia polifolia (S. R. Brinker, sight record).

Kalmia procumbens is a circumpolar arctic and subarctic low shrub, widespread in northern North America and also occurring in northern Eurasia (Liu et al. 2009). This plant was traditionally placed in the genus Loiseleuria (Loiseleuria procumbens), but Kron et al. (2008) recently included Loiseleuria within Kalmia based on genetic evidence (e.g., Kron 1997), a treat- ment followed by Liu et al. (2009). Although it has been mapped from Ontario by Liu et al. (2009), we are not aware of the basis for this report; the species is not attributed to the province by Scoggan (1979), Morton and Venn (1990), Newmaster et al. (1998), Kartesz (1999), or Riley (2003). Soper and Heimburger (1982) suggested that $K$. procumbens should be expected in Ontario, based on its distribution in adjacent Manitoba and Quebec. An earlier literature report from Hawley Lake, Kenora District, Ontario, by Kershaw and Rouse (1971) was excluded by Riley (2003) because it was not based on any collected voucher specimens, nor was Riley aware of any Ontario collections or other reports.

Kalmia procumbens is known elsewhere in the Hudson Bay region from northeastern Manitoba, south to Churchill, and from islands in James Bay, Quebec (Scoggan 1979). According to Johnson (1987), it is locally common on dry peat in the Churchill area. Riley (2003) provided a distribution map of the eastern Canadian distribution.

\section{Saxifragaceae}

Saxifraga rivularis L. (Alpine Brook Saxifrage)KENORA DISTRICT: Precambrian bedrock outcrop, ca. $65 \mathrm{~km} \mathrm{~S}$ of Hudson Bay coast, ca. $83 \mathrm{~km}$ ESE of Peawanuck, cool, moist, shaded talus at north-facing base of outcrop, in moss mat with Cystopteris fragilis 


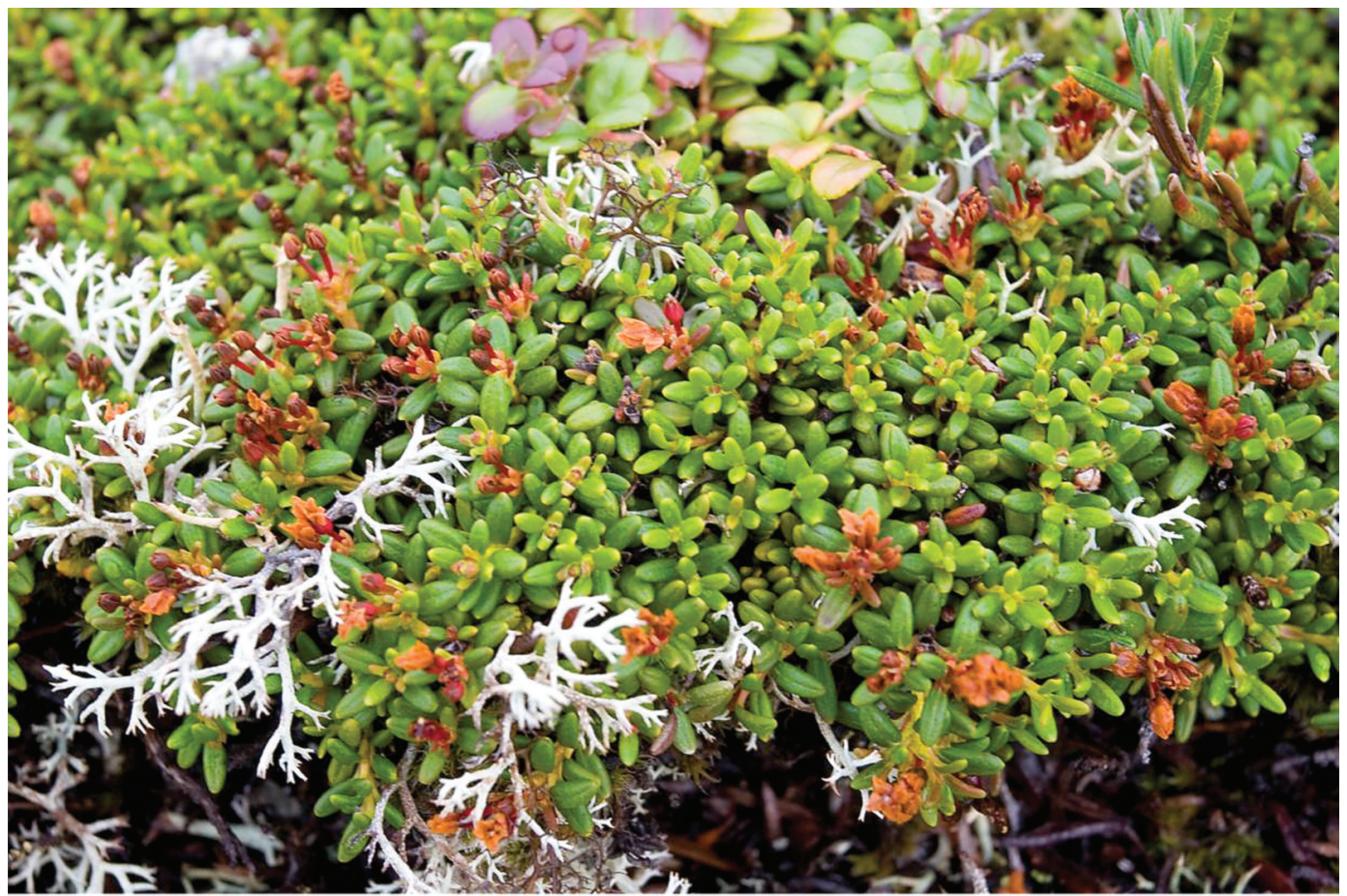

Figure 4. Alpine Azalea (Kalmia procumbens) on the Sutton Ridges, Ontario, 3 July 2010. Photo: S. R. Brinker.

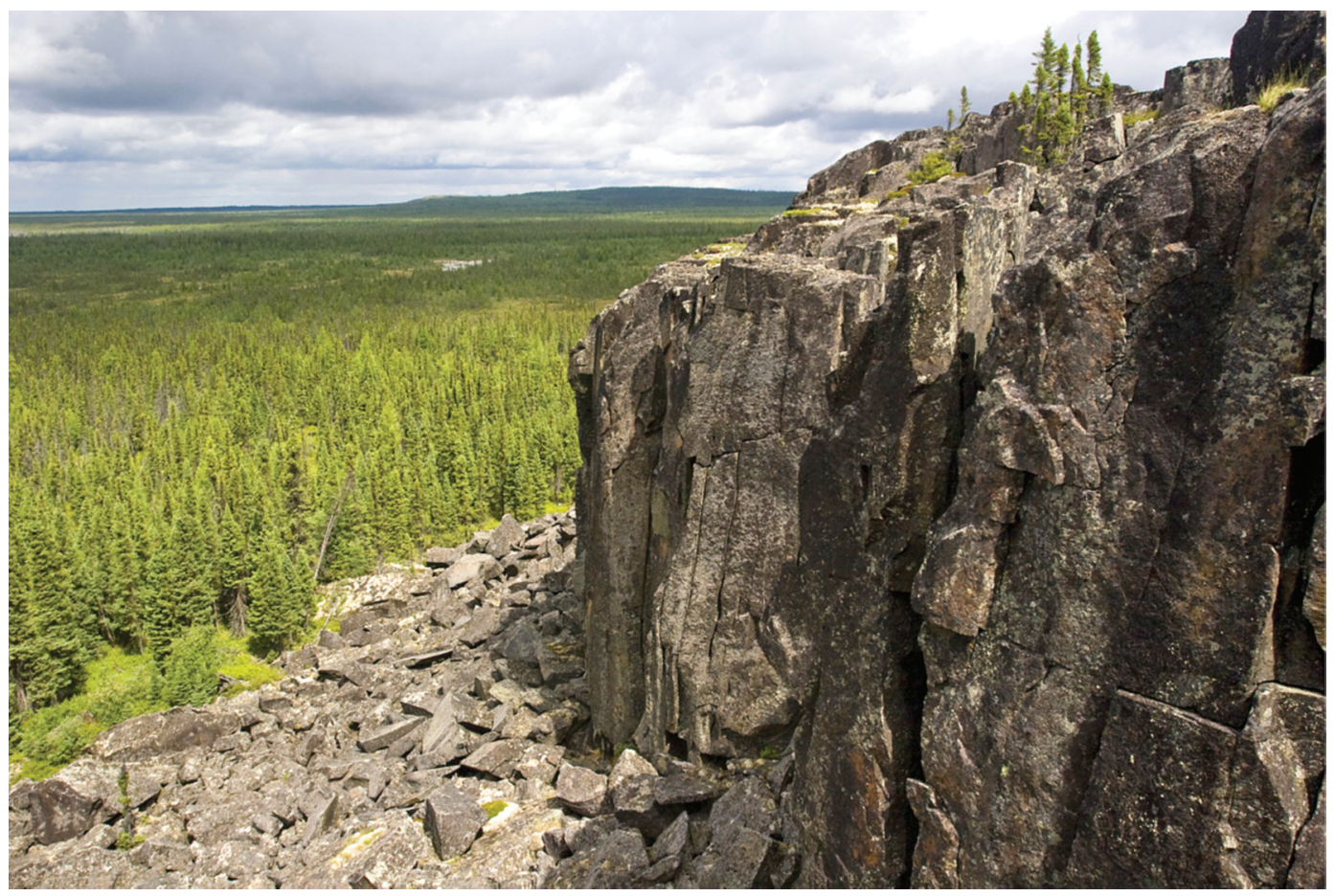

FIGURE 5. Sutton Ridge Precambrian granitic inlier, with talus, cliff, and rim communities, noted for their concentrations of rare species, 9 July 2010. Photo: S. R. Brinker. 


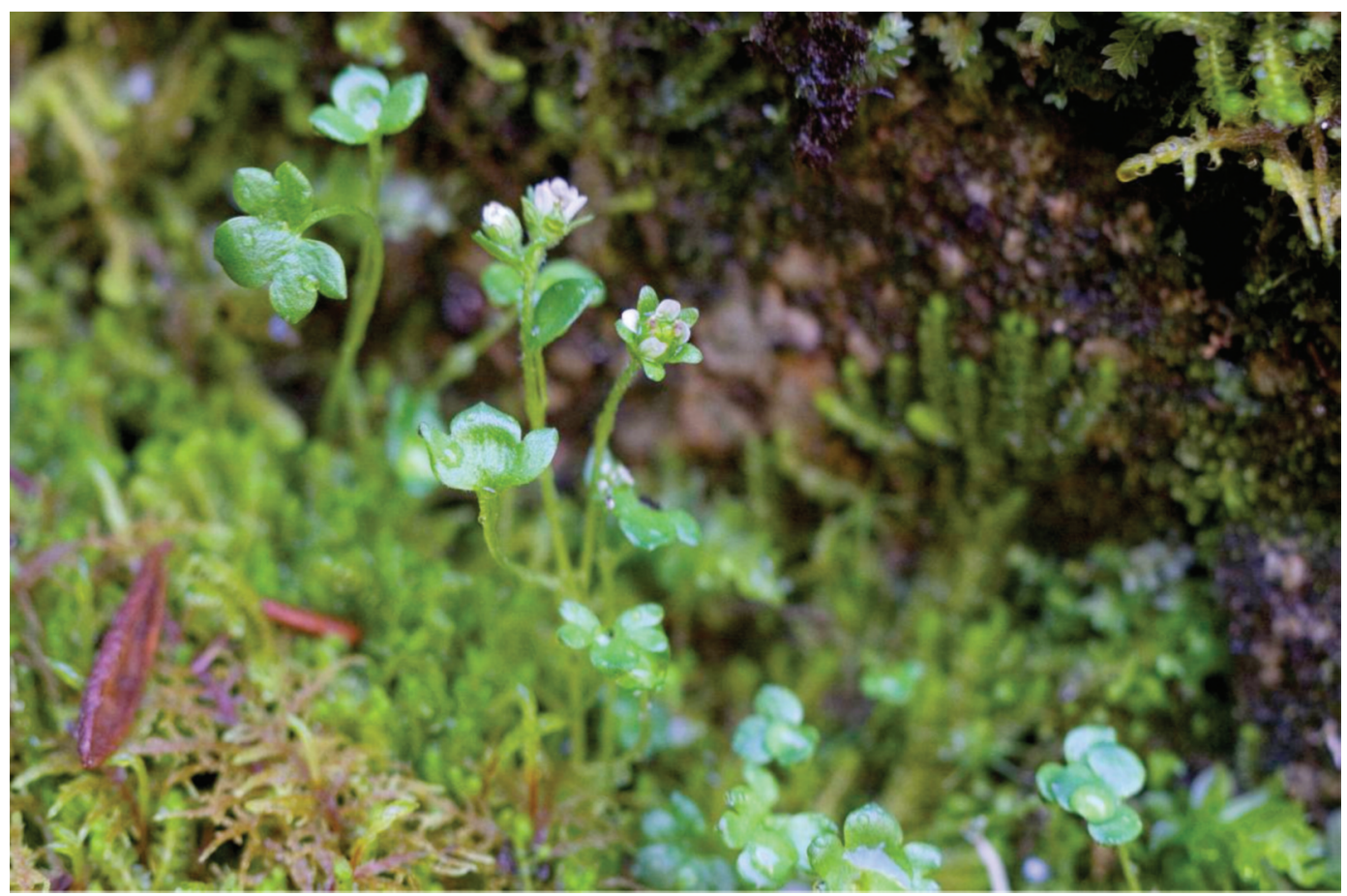

FIgURE 6. Alpine Brook Saxifrage (Saxifraga rivularis) on the Sutton Ridges, Ontario, 11 July 2010. Photo: S. R. Brinker.

and Rubus chamaemorus, with Rhododendron groenlandicum nearby, $54.689,-84.263$, 6 July 2010, M. J. Oldham \& C. Latremouille 37801 (NHIC, TRT, determined by R. Elven, March 2011); Precambrian bedrock outcrop, $84 \mathrm{~km}$ ESE of Peawanuck Airport, $27 \mathrm{~km}$ ENE of Hawley Lake, 20 mostly non-flowering plants in moist, shaded north-facing moss-covered rock crevice and talus with Spreading Woodfern (Dryopteris expansa), Empetrum nigrum, Rhododendron tomentosum, Skunk Currant (Ribes glandulosum), and Long Beechfern (Phegopteris connectilis), 54.703, -84.225, 11 July 2010, S. R. Brinker 1728 (CAN, MICH).

In 2010, Saxifraga rivularis (Figure 6) was located at two sites on the Sutton Ridges. Saxifraga rivularis presents one of the most extreme disjunctions known in the arctic flora: it has a small amphi-Beringian range (Saxifraga rivularis subsp. arctolitoralis) and a larger amphi-Atlantic one (Saxifraga rivularis subsp. rivularis) (Westergaard et al. 2010). Ontario plants belong to subsp. rivularis (Brouillet and Elvander 2009). Saxifraga rivularis belongs to a taxonomically complex group of arctic-alpine plant species (Jørgensen et al. 2006) found in northern areas of North America and Europe (Hollingsworth et al. 1998). The group consists of small perennial herbs with palmate leaves, rounded leaf lobes, and small white or pink flowers. Scoggan (1978), Johnson (1987), Blondeau and Cayouette (2002), and Riley (2003, based on Brown 695, 1951,
CAN) report the species from Churchill, Manitoba, although Brouillet and Elvander (2009) do not map it from the province and Brouillet et al. (2011*) exclude the species from Manitoba. It is known from nearby Quebec at Pointe Louis-XIV (Cape Jones) in southeastern Hudson Bay (Scoggan 1978) and elsewhere along the east coast of James and Hudson bays (Blondeau and Cayouette 2002). Reidar Elvin (personal communication, 18 March 2011) confirmed the identification of one of the Ontario $S$. rivularis specimens ( $M$. J. Oldham \& C. Latremouille 37801).

\section{Acknowledgements}

We would like to gratefully acknowledge the support and assistance of the Weenusk First Nation for permitting access to its traditional lands and for facilitating our fieldwork. Bruce Bennett, Paul Catling, Bill Crins, and John Riley provided helpful comments on the manuscript. The following individuals assisted with fieldwork: Bill Crins, Colin Jones, Zaid Jumean, Rachelle Lalonde, Charles Latremouille, and Don Sutherland. Reidar Elven (University of Oslo) confirmed the identification of one of our Saxifraga rivularis collections, and he and Marte Holten Jørgensen examined and agreed with the identification of the photograph of $S$. rivularis in Figure 6. The Ontario Ministry of Natural Resources supported publication costs. 
Documents Cited (marked $*$ in text)

Brouillet, L., F. Coursol, M. Favreau, M. Anions, P. Bélisle, and P. Desmet. 2011. VASCAN, the Database of Vascular Plants of Canada. http://data.canadensys.net/vascan (accessed 6 December 2011).

Ontario Ministry of Natural Resources. 2012. Ontario Biodiversity Explorer [web application]. Version 1.2. Natural Heritage Information Centre, Peterborough, Ontario. https://www.biodiversityexplorer.mnr.gov.on.ca/nhicWEB /main.jsp (accessed 14 February 2012).

Thiers, B. 2011. Index Herbariorum: A global directory of public herbaria and associated staff. New York Botanical Garden's Virtual Herbarium. http://sciweb.nybg.org/science 2/IndexHerbariorum.asp.

\section{Literature Cited}

Egisdóttir, H. H., and T. E. Thórhallsdóttir. 2006. Breeding system evolution in the Arctic: a comparative study of Campanula uniflora in Greenland and Iceland. Arctic, Antarctic, and Alpine Research 38(3): 305-312.

Blondeau, M., and J. Cayouette. 2002. La flore vasculaire de la Baie Wakeham et du Havre Douglas, Détroit d'Hudson, Nunavik, Québec. Provancheria 28. Université Laval, Québec. 184 pages.

Brouillet, L., and P. E. Elvander. 2009. Saxifraga. Pages 132-146 in Magnoliophyta: Paeoniaceae to Ericaceae. Vol. 8 of the Flora of North America North of Mexico. Edited by the Flora of North America Editorial Committee. Oxford University Press, New York.

Day, R. T., and P. J. Scott. 1981. Autecological aspects of Diapensia lapponica L. in Newfoundland. Rhodora 83: 101109.

Day, R. T., and P. J. Scott. 1984. The biology of Diapensia lapponica in Newfoundland. Canadian Field-Naturalist 98(4): 425-439.

Hollingsworth, P. M., M. Tebbitt, K. J. Watson, and R. J. Gornall. 1998. Conservation genetics of an arctic species, Saxifraga rivularis L., in Britain. Botanical Journal of the Linnean Society 128: 1-14.

Hultén, E. 1968. Flora of Alaska and neighbouring territories: a manual of the vascular plants. Stanford University Press, Stanford, California. 1008 pages.

Johnson, K. L. 1987. Wildflowers of Churchill and the Hudson Bay Region. Manitoba Museum of Man and Nature, Winnipeg. 400 pages.

Jørgensen, M. H., R. Elven, A. Tribsch, T. M. Gabrielsen, B. Stedje, and C. Brochmann. 2006. Taxonomy and evolutionary relationships in the Saxifraga rivularis complex. Systematic Botany 31: 702-729.

Kartesz, J. T. 1999. A synonymized checklist and atlas with biological attributes for the vascular flora of the United States, Canada, and Greenland. First edition. In Synthesis of the North American Flora, Version 1.0. Edited by J. T. Kartesz and C. A. Meacham. North Carolina Botanical Garden, Chapel Hill, N.C. CD-ROM.

Kershaw, K. A., and W. R. Rouse. 1971. Studies on lichendominated systems. I. The water relations of Cladonia alpestris in spruce-lichen woodland in northern Ontario. Canadian Journal of Botany 49: 1389-1399.

Kron, K. A. 1997. Phylogenetic relations of Rhododendroidea (Ericaceae). American Journal of Botany 84(8): 973-980.

Kron, K. A., W. S. Judd, and A. A. Anderberg. 2008. Validation of Kalmia buxifolia (Bergius) Gift \& Kron and Kalmia procumbens (L.) Gift \& Kron. Nordic Journal of Botany 26: 47-48.

Liu, S., K. E. Denford, J. E. Ebinger, J. G. Packer, and G. C. Tucker. 2009. Kalmia. Pages 480-485 in Magnoliophyta: Paeoniaceae to Ericaceae. Vol. 8 of the Flora of North America north of Mexico. Edited by the Flora of North America Editorial Committee. Oxford University Press, New York.

McAndrews, J. H., J. L. Riley, and A. M. Davis. 1982. Vegetation history of the Hudson Bay Lowland: a postglacial pollen diagram from the Sutton Ridge. Naturaliste canadien 109: 597-608.

Morton, J. K., and J. M. Venn. 1990. A checklist of the flora of Ontario vascular plants. University of Waterloo Biology Series, Waterloo, Canada. 218 pages.

Nesom, G. L. 2009. Diapensia. Pages 337-338 in Magnoliophyta: Paeoniaceae to Ericaceae. Vol. 8 of the Flora of North America north of Mexico. Edited by the Flora of North America Editorial Committee. Oxford University Press, New York.

Newmaster, S. G., A. Lehela, P. W. C. Uhlig, S. McMurray, and M. J. Oldham. 1998. Ontario Plant List. Forest Research Information Paper No. 123, Ontario Forest Research Institute, Ontario Ministry of Natural Resources, Sault Ste. Marie, Ontario. 550 pages + appendices.

Riley, J. L. 2003. Flora of the Hudson Bay Lowland and its Postglacial Origins. NRC Research Press, Ottawa, Ontario. 236 pages.

Riley, J. L. 2011. Wetlands of the Ontario Hudson Bay Lowland: an Ontario overview. Nature Conservancy of Canada, Toronto, Ontario. 156 pages + appendices. http://www. ontla.on.ca/library/repository/mon/25007/311168.pdf.

Riley, J. L., and S. Walshe. 1985. New and interesting vascular plant records from northern Ontario. Canadian FieldNaturalist 99(1): 30-33.

Scoggan, H. J. 1978. The Flora of Canada. Part 3: Dicotyledoneae (Saururaceae to Violaceae). Publications in Botany No. 7(2). National Museum of Natural Sciences, Ottawa. 568 pages.

Scoggan, H. J. 1979. The Flora of Canada. Part 4: Dicotyledoneae (Loasaceae to Compositae). Publications in Botany No. 7(4). National Museum of Natural Sciences, Ottawa. 594 pages.

Soper, J. H., and M. L. Heimburger. 1982. Shrubs of Ontario. Royal Ontario Museum, Toronto, Canada. 495 pages.

Westergaard, K. B., M. H. Jørgensen, T. M. Gabrielsen, I. G. Alsos, and C. Brochmann. 2010. The extreme Beringian/Atlantic disjunction in Saxifraga rivularis (Saxifragaceae) has formed at least twice. Journal of Biogeography 37: 1262-1276.

Received 21 December 2011

Accepted 11 January 2012 